\title{
Can Ozone be a New Control Strategy for Pests of Stored Grain?
}

\author{
Fuji Jian · Digvir S. Jayas · Noel D. G. White
}

Received: 30 September 2012/Accepted: 27 December 2012/Published online: 30 January 2013

(C) NAAS (National Academy of Agricultural Sciences) 2013

\begin{abstract}
Ozone $\left(\mathrm{O}_{3}\right)$ is a strong oxidant with a long history of safe use in many fields. Researches have been recently focused on the application of $\mathrm{O}_{3}$ as a fumigant to control stored-grain insects and microorganisms and to reduce mycotoxins. This review found the following facts: (1) $\mathrm{O}_{3}$ significantly suppressed insect populations at $\leq 50$ ppm with 4 days treatment; (2) to eradicate insect infestation, $>135 \mathrm{ppm}$ with more than 8 days treatment would be required; (3) $\mathrm{O}_{3}$ at $50 \mathrm{ppm}$ with 3 days treatment reduced $63 \%$ of stored fungi; (4) $\mathrm{O}_{3}$ at 5-30 ppm could reduce mycotoxin contamination; however, high concentration and long treatment time were required to eliminate mycotoxins; (5) application of $\mathrm{O}_{3}$ at doses that were sufficient for the effective disinfestation of grain might affect qualities of grain; and (6) $\mathrm{O}_{3}$ at 47-106 ppm could noticeably damage equipment in 2 months by corrosion. Based on these facts, we recommended that $\leq 50$ ppm $\mathrm{O}_{3}$ should be used in the stored-grain industry and its potential method of application was also analyzed.
\end{abstract}

Keywords Stored grain $\cdot$ Ozone $\cdot$ Insects $\cdot$ Microorganisms $\cdot$ Mycotoxins $\cdot$ Decontamination $\cdot$ Disinfestation

\section{Introduction}

Ozone $\left(\mathrm{O}_{3}\right)$, or trioxygen, is much less stable than $\mathrm{O}_{2}$ and breaks down with a half-life of $20-50 \mathrm{~min}$ at room temperature, to normal $\mathrm{O}_{2}$. Ozone is a strong oxidant with a long history of safe use in many fields and mostly used in the industries of pharmaceuticals, synthetic lubricants, and many other organic compounds. It is also used for bleaching substances, controlling microorganisms in water and air sources, eradicating water-borne parasites, and bleaching wood pulp and paper. For example, $\mathrm{O}_{3}$ was first used to treat water as early as $1893[12,27]$. At present, many municipal water treatment systems control bacteria with $\mathrm{O}_{3}$ instead of chlorine $[12,15,47]$. Once it has

F. Jian · D. S. Jayas $(\square)$

Department of Biosystems Engineering, University

of Manitoba, Winnipeg, MB R3T 5V6, Canada

e-mail: digvir_jayas@umanitoba.ca

N. D. G. White

Agriculture and Agri-Food Canada, Cereal Research Centre,

195 Dafoe Road, Winnipeg, MB R3T 2M9, Canada decayed, $\mathrm{O}_{3}$ leaves no taste or odour in the treated materials [8]. It is also used to treat cold room air, eliminate odours, improve taste, and bleach colour [24].

Since 1930s, researches have been done on a wide variety of fruits and vegetables [46]. These researches used $\mathrm{O}_{3}$ to prevent microorganism activity on food surfaces and extended the shelf life of fruits and vegetables, including apples, oranges, peaches, pears, grapes, cranberries, strawberry, broccoli, potatoes, and tomatoes. For decades, $\mathrm{O}_{3}$ was successfully used as a disinfectant and sanitizer for the treatment of agriculture products and equipment such as vegetables and fruits, dairy and swine effluent, meat, gelatin, manufacturing equipment, and packaging materials [16], to control insects and microorganisms, and to remove pesticides, inorganic and organic compounds [27].

The advantage of $\mathrm{O}_{3}$ application is that it is more environmentally friendly than traditional pesticides and fungicides. Ozone can be easily generated at the treatment site and only electricity and air are required. Therefore, $\mathrm{O}_{3}$ provides several safety advantages over conventional pesticides and fungicides. There are no residues on products and no presence of toxic chemicals, no danger of chemical 
mixing hazards, or no issues about disposal of left over insecticides or containers [25].

Researches have been recently focused on the application of $\mathrm{O}_{3}$ as a fumigant to control stored-grain insects and microorganisms and to reduce mycotoxins on grain. This attention is timely due to the development of insect resistance to pesticides, the phase out of methyl bromide in 2005 as a fumigant, increased demand for organic grains, and innovation to control insects and microorganisms. Looking at past literature (especially the last 2 years), we saw rapidly accumulated information on this powerful oxidizing agent. The purpose of this article was to present a general overview of published information related to $\mathrm{O}_{3}$ as a fumigant to control insects and microorganisms and to reduce mycotoxins. Its potential application in the grain storage industry was also assessed.

\section{Control of Insects of Stored Grain}

Before 1980, the toxicity of $\mathrm{O}_{3}$ on agriculture field insects was studied [5, 14, 29, 30] and little was known on stored grain insects [13]. In recent years, $\mathrm{O}_{3}$ toxicity on storedgrain insects was evaluated in several laboratory and field studies. Those studies showed the toxic effect of $\mathrm{O}_{3}$ to stored-grain insects. However, there were several inconsistences in the published reports summarized below.

\section{Susceptible Species and Insect Stages}

Ozone was lethal to both external and internal feeders. The external feeders include beetles such as Cryptolestes ferrugineus (Stephens) [6], Oryzaephilus surinamensis (L.) [6, 18, 34, 52], Tribolium castaneum (Herbst) [6, 13, 18, 34], T. confusum (J. Duv.) [13, 18, 34, 52], and Stegobium paniceum (L.) [18]; moths such as Ephestia kuehniella (Zell) [18] and Plodia interpunctella (Hübner) [6, 18, 53]; and Psocids [6]. The internal feeders include weevils such as Sitophilus spp. [6, 18, 53]; lesser grain borer, Rhyzopertha dominica (F.) [6, 18, 52]; and Angoumois grain moth, Sitotroga cerealella (Oliv.) [18]. Studies showed that the most resistant stage of insects was the egg or $\mathrm{O}_{3}$ had no effect on eggs $[6,18,26]$. The susceptible stage among larvae, pupae, and adults was different in different published studies. Bonjour et al. [6] and Hansen et al. [18] found the pupa or adult was the most susceptible stage for most tested species. Leesch [26] reported pupae of $P$. interpunctella were the most resistance stage after the egg. The dose and exposure times leading to $100 \%$ mortality were not different for young, medium-aged and old larvae of eleven stored-product pests tested [18]. However, Erdman [13] found larval and pupa stages of $T$. castaneum were $\mathrm{O}_{3}$ sensitive with sensitivity decreasing with age.
Leesch [26] found younger pupae of $P$. interpunctella were more susceptible whereas with larvae the opposite was true. Isikber and Oztekin [21] observed a higher susceptibility for larvae, pupae, and adult stages of E. kuehniella (90-100 \%) compared to T. confusum (1.3-22.7\%) under similar experimental conditions. A higher susceptibility rate for insects was reported for $P$. interpunctella compared to the low mortality of $T$. confusum [26]. However, Strait [53] and Hansen et al. [18] reported a high mortality rate of T. confusum (Table 1). Ozone treatment on larvae of $P$. interpunctella inside a wheat bin was less effective than that on pupae [6]. Bonjour et al. [6] found S. oryzae adults were the most susceptible species with $100 \%$ mortality reached after 2 days in all $\mathrm{O}_{3}$ treatments (from 25 to 70 ppm). Hansen et al. [18] found S. oryzae adults were not the most susceptible species with $100 \%$ mortality reached after 6 days with $21 \mathrm{ppm} \mathrm{O}_{3}$ treatment.

\section{Dose and Exposure Time}

Lethal dose and exposure time were reported to range between 5 and $500 \mathrm{ppm}$ with a few hours up to 8 days treatments. Leesch [26] used up to $500 \mathrm{ppm}$ in a study to develop relationship of dose and mortality. The author found that $200-500 \mathrm{ppm}$ with many hours was required to kill insects [26]. Hansen et al. [18] found "freely exposed stages (with a few exceptions) were controlled with $35 \mathrm{ppm}$ of $\mathrm{O}_{3}$ in 6 days, while full mortality of internal stages within kernels required exposure to $135 \mathrm{ppm}$ for 8 days". Inside grain bins, $\geq 35 \mathrm{ppm}$ was required for the control of freely exposed stages (Table 1). Inside different media, the same dose and treatment time would not reach the same mortality (Table 1). This difference was caused by the different structures and chemical components on the surface of the materials. Different structures and chemical components would influence the reaction of ozone on the surface of the materials.

Correlation Between Insect Respiration Rate and Their Susceptibility to $\mathrm{O}_{3}$

Ozone-caused tissue damage even at low concentrations $[4,7,31]$. If the insect respiratory system was the major entry route of $\mathrm{O}_{3}$ into the insect body [31], increased respiration rate with an increase of temperature might result in more mortality because the increased gas exchange would increase the amount of $\mathrm{O}_{3}$ inside insect bodies [41, 49]. Sousa et al. [51] and Pereira et al. [41] found the $\mathrm{O}_{3}$ toxicity increased with the increase of the grain temperature and $\mathrm{O}_{3}$ concentration. Carbon dioxide, a respiratory stimulus and synergising agent that acts by keeping insect spiracles open, did potentiate the toxicity of $\mathrm{O}_{3}$ [26]; however, Sousa et al. [52] found there was no correlation 
Table 1 Comparison of disinfestation results of adult insect pests under different treatment conditions

\begin{tabular}{|c|c|c|c|c|c|}
\hline Insects & Media $^{a}$ & $\begin{array}{l}\text { Dose } \\
\text { (ppm) }\end{array}$ & $\begin{array}{l}\text { Time }^{\mathrm{b}} \\
\text { (days) }\end{array}$ & $\begin{array}{l}\text { Mortality } \\
(\%)\end{array}$ & Source \\
\hline \multirow[t]{5}{*}{$R$. dominica } & $\begin{array}{c}\text { Wheat } \\
\text { bin }\end{array}$ & 70 & 4 & 97 & $\begin{array}{l}\text { Bonjour } \\
\text { et al. [6] }\end{array}$ \\
\hline & $\begin{array}{l}\text { Freely } \\
\text { exposed }\end{array}$ & 35 & 6 & 100 & $\begin{array}{l}\text { Hansen } \\
\text { et al. }[18\end{array}$ \\
\hline & $\begin{array}{r}\text { Inside } \\
\text { corn }\end{array}$ & 120 & 1.2 & $100^{\mathrm{d}}$ & $\begin{array}{c}\text { Qin et al. } \\
\text { [44] }\end{array}$ \\
\hline & $\begin{array}{l}\text { Inside } \\
\text { wheat }\end{array}$ & 120 & 1.2 & $100^{\mathrm{d}}$ & $\begin{array}{l}\text { Qin et al. } \\
\text { [44] }\end{array}$ \\
\hline & $\begin{array}{l}\text { Inside } \\
\text { paddy }\end{array}$ & 120 & 1.2 & 94 & $\begin{array}{l}\text { Qin et al. } \\
\text { [44] }\end{array}$ \\
\hline \multirow[t]{2}{*}{$\begin{array}{l}\text { Tribolium } \\
\text { confusum }\end{array}$} & $\begin{array}{r}\text { Inside } \\
\text { corn }\end{array}$ & 50 & 3 & 100 & Strait [53] \\
\hline & $\begin{array}{l}\text { Freely } \\
\text { exposed }\end{array}$ & 35 & 6 & 100 & $\begin{array}{l}\text { Hansen } \\
\text { et al. }[18]\end{array}$ \\
\hline \multirow[t]{8}{*}{ T. castaneum } & Corn bin & 50 & 3 & 92 & $\begin{array}{c}\text { Kells et al. } \\
{[23]}\end{array}$ \\
\hline & & 25 & 5 & 77 & $\begin{array}{c}\text { Kells et al. } \\
\text { [23] }\end{array}$ \\
\hline & $\begin{array}{c}\text { Wheat } \\
\text { bin }\end{array}$ & 50 & 4 & 100 & $\begin{array}{l}\text { Bonjour } \\
\text { et al. [6] }\end{array}$ \\
\hline & $\begin{array}{l}\text { Freely } \\
\text { exposed }\end{array}$ & 35 & 6 & 100 & $\begin{array}{l}\text { Hansen } \\
\text { et al. }[18]\end{array}$ \\
\hline & $\begin{array}{r}\text { Inside } \\
\text { corn }\end{array}$ & 50 & 3 & 50 & $\begin{array}{l}\text { Pereira } \\
\text { et al. }[41]\end{array}$ \\
\hline & & 120 & 1.2 & $93^{d}$ & $\begin{array}{l}\text { Qin et al. } \\
\text { [44] }\end{array}$ \\
\hline & $\begin{array}{l}\text { Inside } \\
\text { wheat }\end{array}$ & 120 & 1.2 & $90^{\mathrm{d}}$ & $\begin{array}{l}\text { Qin et al. } \\
\text { [44] }\end{array}$ \\
\hline & $\begin{array}{l}\text { Inside } \\
\text { paddy }\end{array}$ & 120 & 1.2 & $88^{\mathrm{d}}$ & $\begin{array}{l}\text { Qin et al. } \\
\text { [44] }\end{array}$ \\
\hline \multirow[t]{2}{*}{ O. surinamensis } & $\begin{array}{l}\text { Freely } \\
\text { exposed }\end{array}$ & 5 & 3 & 100 & $\begin{array}{l}\text { Mason } \\
\text { et al. }[34]\end{array}$ \\
\hline & $\begin{array}{c}\text { Wheat } \\
\text { bin }\end{array}$ & 70 & 4 & 67 & $\begin{array}{l}\text { Bonjour } \\
\text { et al. [6] }\end{array}$ \\
\hline \multirow[t]{7}{*}{$\begin{array}{r}\text { Sitophilus } \\
\text { zeamais }\end{array}$} & Corn bin & 50 & 3 & 100 & $\begin{array}{c}\text { Kells et al. } \\
\text { [23] and } \\
\text { Strait } \\
{[53]}\end{array}$ \\
\hline & & 25 & 5 & 99 & $\begin{array}{c}\text { Kells et al. } \\
\text { [23] }\end{array}$ \\
\hline & $\begin{array}{l}\text { Freely } \\
\text { exposed }\end{array}$ & 78 & 5 & 100 & $\begin{array}{l}\text { Hansen } \\
\text { et al. }[18\end{array}$ \\
\hline & $\begin{array}{r}\text { Inside } \\
\text { corn }\end{array}$ & 120 & 1.2 & $97^{\mathrm{d}}$ & $\begin{array}{l}\text { Qin et al. } \\
\text { [44] }\end{array}$ \\
\hline & $\begin{array}{l}\text { Inside } \\
\text { wheat }\end{array}$ & 120 & 1.2 & $70^{\mathrm{d}}$ & $\begin{array}{l}\text { Qin et al. } \\
\text { [44] }\end{array}$ \\
\hline & $\begin{array}{l}\text { Inside } \\
\text { paddy }\end{array}$ & 120 & 1.2 & $100^{\mathrm{d}}$ & $\begin{array}{l}\text { Qin et al. } \\
\text { [44] }\end{array}$ \\
\hline & $\begin{array}{l}\text { Freely } \\
\quad \text { exposed }\end{array}$ & 100 & 1 & 100 & $\begin{array}{c}\text { Qin et al. } \\
\text { [44] }\end{array}$ \\
\hline
\end{tabular}

Table 1 continued

\begin{tabular}{|c|c|c|c|c|c|}
\hline Insects & Media $^{\mathrm{a}}$ & $\begin{array}{l}\text { Dose } \\
(\mathrm{ppm})\end{array}$ & $\begin{array}{l}\text { Time }^{\mathrm{b}} \\
\text { (days) }\end{array}$ & $\begin{array}{l}\text { Mortality } \\
(\%)\end{array}$ & Source \\
\hline \multirow[t]{2}{*}{$\begin{array}{c}\text { Sitophilus } \\
\text { oryzae }\end{array}$} & $\begin{array}{l}\text { Wheat } \\
\text { bin }\end{array}$ & 50 & 4 & 100 & $\begin{array}{l}\text { Bonjour } \\
\text { et al. [6] }\end{array}$ \\
\hline & $\begin{array}{l}\text { Freely } \\
\text { exposed }\end{array}$ & 21 & 5 & 100 & $\begin{array}{l}\text { Hansen } \\
\text { et al. [18] }\end{array}$ \\
\hline \multirow[t]{3}{*}{$\begin{array}{l}P . \\
\text { interpunctella }^{\mathrm{c}}\end{array}$} & $\begin{array}{r}\text { Inside } \\
\text { corn }\end{array}$ & 50 & 3 & 100 & Strait [53] \\
\hline & Corn bin & 25 & 5 & 91 & $\begin{array}{l}\text { Kells et al. } \\
\text { [23] }\end{array}$ \\
\hline & $\begin{array}{l}\text { Freely } \\
\text { exposed }\end{array}$ & 36 & 6 & 100 & $\begin{array}{l}\text { Hansen } \\
\text { et al. [18 }\end{array}$ \\
\hline
\end{tabular}

${ }^{a}$ Insects are kept inside cages located in grain bin (corn or wheat bin), in small tubes with small amount grain (inside corn or wheat) or there is no or small amount grain (freely exposed) during treatment

b Time exposed to $\mathrm{O}_{3}$

c Older larval

d Phosphine-resistant strain

between insect respiration rate and their susceptibility to $\mathrm{O}_{3}$. Therefore, the reasons causing insect death should be further studied.

Correlation Between the Resistance to Phosphine and Susceptible to $\mathrm{O}_{3}$

There was no significant correlation between the resistance to phosphine and susceptibility to $\mathrm{O}_{3}$, which clearly indicated the absence of cross-resistance to both fumigants [52]. However, Qin et al. [44] found phosphine resistant strains were more susceptible to $\mathrm{O}_{3}$.

These discrepancies created the difficulty to correctly choose $\mathrm{O}_{3}$ dose and treatment time in grain storage bins. Further testing inside storage bins showed that $\mathrm{O}_{3}$ significantly suppresses insect populations [6, 23]; however, $100 \%$ mortality inside storage bins could only be achieved when much higher $\mathrm{O}_{3}$ concentration and longer treatment time were applied than that under laboratory conditions (Table 1). For example, to reach $100 \%$ mortality inside commercial bins, higher than $70 \mathrm{ppm}$ with more than 4 days treatment would be required to kill adults [6]. To control insect eggs, a second treatment after egg hatching was required [6]. The difference between laboratory and field studies might be caused by the highly reactive nature and short half-life time of $\mathrm{O}_{3}$ that limit $\mathrm{O}_{3}$ penetrating into a grain mass and grain kernels. Insects might not receive the supplied does of $\mathrm{O}_{3}$ at the beginning of the fumigation under field conditions. It should not be different under laboratory and field conditions if insects receive the same 
amount of $\mathrm{O}_{3}$. Therefore, insects inside stored grain bins might receive sub-lethal does. Insects receiving a sub-lethal dose or surviving after treatment were sluggish and uncoordinated; however, the survived insects were able to reproduce [53]. To eradicate insect infestation, therefore, $\geq 135 \mathrm{ppm}$ with more than 8 days treatment would be required [18].

\section{Control of Microorganisms and Reduction of Mycotoxins}

The effect of $\mathrm{O}_{3}$ on food microorganisms was reviewed by Rice et al. [46], Kim et al. [24], and Tiwari et al. [55]. Food microorganisms inherently varied in sensitivity to $\mathrm{O}_{3}$ $[24,46]$. The physical state (e.g., the stage of growth, inside or outside of the treated materials, and whether materials were treated before by $\mathrm{O}_{3}$ ) and environmental factors (e.g., $\mathrm{pH}$ of the medium, temperature, and humidity) greatly affected the disinfestation by $\mathrm{O}_{3}$. Yeasts appeared more sensitive than molds to $\mathrm{O}_{3}$ treatment [38, 45]. Ozone also reacted with other particles and compounds present in an environment such as food systems that were rich in organic matter. Therefore, $\mathrm{O}_{3}$ was more effective on microorganisms when the organism was inside water and air or on the surface of treated materials.

Except for a few published papers in the 1960s and 1980s little was known about the effects of $\mathrm{O}_{3}$ on stored grain and associated microorganisms [11, 32, 38-40, 48]. Ozone was effectively used to control stored grain and flour fungal growth; however, these effective results were only presented at certain conditions. Inside cereal grains, beans, and spices, counts of Bacillus and Micrococcus decreased 1-3 logs by $<50 \mathrm{mg} / \mathrm{L} \quad \mathrm{O}_{3}$ treatment [39]; however, with few exceptions, longer exposure time and lower temperature resulted in higher or the same microbial activity. Mason et al. [34] also found radial growth of Aspergillus flavus Link and Fusarium moniliforme J. Sheld in agar media was inhibited for the first 2 days, however after 3 days of $\mathrm{O}_{3}$ exposure, growth of the microorganism was the same as the control. The "number of viable A. parasiticus Speare on the grain surface was reduced by $63 \%$ when grain was exposed to $50 \mathrm{ppm}_{3}$ for 3 days, whereas $25 \mathrm{ppm}$ for 5 days failed to significantly reduce spore viability" [23]. Therefore, researchers concluded that $\mathrm{O}_{3}$ was only effective on microorganisms on the surface of grain kernels and control required higher than $1,752 \mathrm{ppm}$ [2, 23, 34, 35, 57].

Further pilot studies in grain storage bins showed that microorganisms were significantly decreased. Even though increasing treatment time and dose decreased the count of microorganisms, the maximum reduction rate was less than $80 \%$ and only the microorganisms on the surface of the grain kernels were reduced. To reach this maximum reduction rate, $1,752 \mathrm{ppm} \mathrm{O}_{3}$ with $3 \mathrm{~h}$ treatment was required [23, 35]. Kells et al. [23] reported that $50 \mathrm{ppm} \mathrm{O}_{3}$ with 3 days treatment reduced only $63 \%$ of the contamination level of the fungus A. parasiticus. White et al. [57] concluded that $\mathrm{O}_{3}$ treatment decreased dry matter loss compared to the control, but treatment at high rates and long treatment times would result an unacceptable cost for the grain industry. In addition, $\geq 1,752 \mathrm{ppm} \mathrm{O}_{3}$ was corrosive [26]. Therefore, using higher concentration of $\mathrm{O}_{3}$ to control microorganisms in stored grain might not be justified, while lower than $1,752 \mathrm{ppm}$ could only suppress populations of microorganisms.

Ozone was reported to "be effective in the detoxification and degradation of commonly occurring mycotoxins such as patulin, cyclopiazonic acid, secalonic acid $\mathrm{D}$, ochratoxin A, ZEN, aflatoxins, deoxynivalenol" [28, 36, 59]. Decontamination of mycotoxins depended upon several factors including exposure time, $\mathrm{O}_{3}$ concentration, temperature, $\mathrm{pH}$, and moisture content of the grain mass. Application of $\mathrm{O}_{3}$ gas under dry conditions was reported to be less effective than that under moist conditions [59]. Young et al. [60] observed "a rapid degradation of trichothecene mycotoxins at a low $\mathrm{pH}(\mathrm{pH} 4-6)$ compared to a higher $\mathrm{pH}$ (pH 7-8)". Proctor et al. [42] reported "a greater degradation of aflatoxins in peanut kernels at high temperature". Degradation was specific to the molecular structure of toxins. McKenzie et al. [36] observed greater resistance of aflatoxin B2 compared to B1 and G2. To reduce mycotoxin contamination, $\mathrm{O}_{3}$ at about 5-30 ppm was required [55]; however, to eliminate mycotoxins from grain required a high concentration and long treatment time.

\section{Effect on Stored-Grain Quality}

Tiwari et al. [55] reviewed the effect of $\mathrm{O}_{3}$ on grain quality and concluded that application of $\mathrm{O}_{3}$ at doses that were sufficient for the decontamination of grains might affect grain quality. In the published literature, there were discrepancies in the effect of $\mathrm{O}_{3}$ on quality of grain and derived products. These discrepancies might be mainly caused by the difference of dose and treatment time, material, and application method.

The most affected part of the grain kernels or food products was the surfaces of the treated materials [20]. Mechanisms of decomposition by $\mathrm{O}_{3}$ were complex processes that depend on factors such as the surface structure of a grain kernel, its products, and packing density of materials. Ozone converted many nonbiodegradable organic materials into biodegradable forms [24]. Ozone was sparingly soluble in water. At $20{ }^{\circ} \mathrm{C}$, the solubility of $100 \% \mathrm{O}_{3}$ was only $570 \mathrm{mg} / \mathrm{L}$. Ozone decomposed in solution in a stepwise fashion, producing in turn hydroperoxyl $\left({ }^{\circ} \mathrm{HO}_{2}\right)$, hydroxyl 
$\left({ }^{\circ} \mathrm{OH}\right)$, and superoxide $\left({ }^{\circ} \mathrm{O}_{2}{ }^{-}\right)$radicals $[1,17,20]$. Ozone might directly react with substrates with organic double bonds as a general oxidant [54]. When $\mathrm{O}_{3}$ was broken down to dioxygen it gave rise to oxygen-free radicals, which were highly reactive and capable of damaging many organic molecules. These reactions were so rapid and the decomposition of $\mathrm{O}_{3}$ was so fast that its disinfestation action might take place mainly at the surface [20] until a saturation state of $\mathrm{O}_{3}$ was reached. The surface reaction might explain the following experimental reports.

1) During $\mathrm{O}_{3}$ treatment, surface oxidation happened and this oxidation might promote oxidative spoilage, discolouration, and produce undesirable odours [24]. However, the internal part of the treated grain and its products were not affected, and milling and baking quality of these discoloured products might not be influenced. For example, Naitoh et al. [39] found that oxidation of lipids in cereals, peas, beans, and spices rarely occurred at $<5 \mathrm{ppm}$ but was considerable at higher concentrations. The husk of the rice treated with $\mathrm{O}_{3}$ at $50 \mathrm{ppm}$ for 30 days was darker brown than that in the control and had a smell of vinegar and an acidic odour. This acidic odour decreased over time but was still detectable 4 months later. Both the acidic odour and brown discolouration could be removed during the milling process, and the baking and milling quality of the polished rice was not influenced [37]. Mendez et al. [37] also found that amino acid and fatty acid contents and the content of saturated or unsaturated fatty acids of hard and soft wheat, soybean, and maize did not alter. They suggested that the $\mathrm{O}_{3}$ did not penetrate into the kernels. Dehulling of moistened wheat treated with $\mathrm{O}_{3}$ was enhanced [9]. Desvignes et al. [10] observed a "significant reduction (10-20\%) in the required total energy for milling without significant changes in biochemical characters of the milling fractions".

2) Ozone penetrated into the inside of the treated materials. Compared with grain kernels, processed products with low packing density might be easy to be penetrated by $\mathrm{O}_{3}$. Therefore, the baking quality of these processed products might be influenced. For example, $\mathrm{O}_{3}$ treatment of rice starch was reported to "enhance swelling with a reduced retrogradation tendency" [3]. Ozone had a negative effect on the sensory quality of ground spices, milk powder, and fish cake due to lipid oxidation [40]. Thiamin content in wheat flour decreased after $\mathrm{O}_{3}$ treatment [40]. This surface reaction also explained that $\mathrm{O}_{3}$ treatment improved the sensory quality in beef and egg and it did not alter the sensory quality of some fruits and vegetables significantly [24].
3) Germination of treated grain might be influenced by the $\mathrm{O}_{3}$ concentration and treatment time. Germination of corn treated with $20 \mathrm{~g} / \mathrm{m}^{3} \mathrm{O}_{3}$ for $6.8-20.5 \mathrm{~min}$ increased [56]. However, $\mathrm{O}_{3}$ at ground level with a maximum $11 \mathrm{ppm}$ reduced the germination of Northern pine provenances [43]. Wu et al. [58] found germination of wheat was not affected in less than 15 min treatment while it was reduced after $20 \mathrm{~min}$ treatment with $\mathrm{O}_{3}$ concentration at $0.98 \mathrm{mg} / \mathrm{g}$ wheat. Strait [53] found germination of corn is not influenced after ozone treatment.

\section{Toxicity to Humans and Corrosion}

When $\mathrm{O}_{3}$ concentration was less than $0.05 \mathrm{ppm}, \mathrm{O}_{3}$ had a pleasant odour, similar to the fresh air after a thunderstorm. When concentration was higher than this pleasant level, $\mathrm{O}_{3}$ was a primary irritant and affected especially the eyes and respiratory systems. Therefore, $\mathrm{O}_{3}$ was detectable by many people at concentrations of $10 \mathrm{ppm}$ in air. Ozone-damaged respiratory tissues in humans above concentrations of $100 \mathrm{ppm}$. Ground level $\mathrm{O}_{3}$ could harm lung function and irritate the respiratory system. Ozone pollution was linked to premature death, heart attack, bronchitis, asthma, and other cardiopulmonary problems. In the USA, $\mathrm{O}_{3}$ in the work environment was limited to a maximum of $0.1 \mathrm{ppm}$ on a basis of $8 \mathrm{~h}$ per day and $40 \mathrm{~h}$ per week. Risk of $\mathrm{O}_{3}$ to humans could be kept at a minimum level if lower than $50 \mathrm{ppm}$ was applied and treated facilities were sealed.

Ozone is a powerful oxidant, second only to the hydroxyl-free radical. Therefore, it was capable of oxidizing many inorganic and organic compounds in air and water. Ozone could oxidize most metals (except gold, platinum, and iridium) to oxides of the metals or in their highest oxidation state. Ozone attacked copper, silver, aluminium (at damp or wet condition), brass, steel, and iron $[22,26]$. Ozone reacted directly with some hydrocarbons such as aldehydes, polymer, or double bonds within its chain structure such as in natural rubber, wool, protein, and paint. The rubber couplings used to connect PVC ducts to the distribution plenum was rapidly degraded during 2-month duration of the test with $\mathrm{O}_{3}$ concentration from 47 to $106 \mathrm{ppm}$ [19]. Corrosion by $\mathrm{O}_{3}$ to materials used by the grain industry was a potential disadvantage for $\mathrm{O}_{3}$ application and should be evaluated. One of the choices to reduce the corrosion might be that the grain storage and handling system was protected by ozone-resistant materials. Ozone-resistant materials included the austenitic (300 series) stainless steels, titanium, glass, ceramics, concrete, waxes, Teflon, Hypalon ${ }^{\circledR}$, polytetrafluorethylene, or polyvinylidene fluoride. 
Ozone must be continually supplied and evenly distributed throughout bulk of grain. It might increase corrosion rates on metal components and degrade equipment such as rubber seals, and electrical equipment at unacceptable rates [19]. Therefore, to reduce the corrosion, $\mathrm{O}_{3}$ should be used at low concentration and contact between $\mathrm{O}_{3}$ and equipment should be minimized. These disadvantages required complex application techniques such as mixing with treated materials which make $\mathrm{O}_{3}$ treatment much more complicated than conventional treatments. This might result in a high cost of equipment and operational costs.

\section{Application of $\mathrm{O}_{3}$}

Because most microorganisms, mycotoxins, and insects might not be found in free suspension as discrete particles or on the surface of the treated materials, the effectiveness of $\mathrm{O}_{3}$ depended on the amount of $\mathrm{O}_{3}$ applied but more on the $\mathrm{O}_{3}$ reacting with the microorganisms, mycotoxins, and insects after demands by the substrate organic matter had been met or the organic matter was saturated with $\mathrm{O}_{3}$. In the published studies, there were discrepancies on the effect of $\mathrm{O}_{3}$ on insects, microorganisms, and mycotoxins. These discrepancies might be caused by the highly reactive nature and short half-life time of $\mathrm{O}_{3}$ that limit $\mathrm{O}_{3}$ penetrating into grain mass and grain kernels. Therefore, the most failures by various investigators might be their inability to distinguish between the concentration of applied $\mathrm{O}_{3}$ and $\mathrm{O}_{3}$ reacting with microorganisms, mycotoxins, and insects.

This review found the following facts: (1) $\mathrm{O}_{3}$ significantly suppressed insect populations at $50 \mathrm{ppm}$ with 4 days treatment; (2) to eradicate insect infestation, $\geq 135 \mathrm{ppm}$ with more than 8 days treatment would be required; (3) $\mathrm{O}_{3}$ at $50 \mathrm{ppm}$ with 3 days treatment reduced $63 \%$ of the contamination level of fungi and even $>50 \mathrm{ppm}$ with longtreatment time might not eliminate fungi; (4) to reduce mycotoxin contamination, $\mathrm{O}_{3}$ at 5-30 ppm was required; however, to eliminate mycotoxins from grain required a high concentration and long treatment time; (5) application of $\mathrm{O}_{3}$ at doses that were sufficient for the disinfestation of grain might affect grain qualities; and (6) $\mathrm{O}_{3}$ at 47-106 ppm could seriously damage the rubber couplings in 2 months. Therefore, $\mathrm{O}_{3}$ at $50 \mathrm{ppm}$ might be the proper dose to be used to suppress insect and microorganism populations and reduce mycotoxins. To exterminate insects, microorganisms, and mycotoxin contamination, a much higher dose will be required but it might not be justified because the complex application technique and requirement of ozone-resistant materials would result in a cost challenge for the grain storage industry. This recommended dose might be used in the fumigation of empty facilities and grain storage bins.

\section{Empty Facility and Flour Mill Treatment}

Empty facility and flour mill treatment with $\mathrm{O}_{3}$ might be more effective and faster than that inside grain storage bins if corrosion was not an issue. Because empty facilities have less grain mass than inside grain bins, the total amount of $\mathrm{O}_{3}$ applied to the empty facility would be much lower. Insects and microorganisms would also be directly exposed to the applied dose of $\mathrm{O}_{3}$. Ozone fumigation might be applied on a room to room basis if each room was airtight enough to stop $\mathrm{O}_{3}$ leakage. This might avoid shutting down the entire facility. There were several reports on storage room treatments with $\mathrm{O}_{3}$ [46].

\section{Application in Stored Grain Bins}

Even though the chemical components on the grain surface that react with $\mathrm{O}_{3}$ were not well known, studies showed that $\mathrm{O}_{3}$ movement through a grain mass was restricted [23, 37]. When $\mathrm{O}_{3}$ reached the grain, most of the $\mathrm{O}_{3}$ reacted with the grain and only a small amount reacted with pathogens or insects unless pathogens and insects were located on the surface of treated materials or the surface of the treated materials was saturated with $\mathrm{O}_{3}$. This surface reaction explained two distinct phases of $\mathrm{O}_{3}$ movement in bulk grain [23, 53]. When grain was not saturated with $\mathrm{O}_{3}$ (phase one), $\mathrm{O}_{3}$ was reduced as it moved through a grain mass because interaction with grain rapidly degraded the $\mathrm{O}_{3}$. Once the grain was saturated with $\mathrm{O}_{3}$ (phase two), $\mathrm{O}_{3}$ could be moved through the grain mass with less degradation. For example, $\mathrm{O}_{3}$ concentration at $2.7 \mathrm{~m}$ high in a bulk of stored corn could reach $50 \mathrm{ppm}$ in 0.7 day when $\mathrm{O}_{3}$ was pushed with an apparent velocity of $0.03 \mathrm{~m} / \mathrm{s}$ and $\mathrm{O}_{3}$ concentration supplied at the bottom of the bulk grain was $80 \mathrm{ppm}$ (calculated from the equation published by Mendez et al. [37]). In both the USA and Canada, grain is usually stored inside silos higher than $6 \mathrm{~m}$ and larger than $6 \mathrm{~m}$ diameter. If $50 \mathrm{ppm}$ was the lethal dose and the apparent air velocity was $0.03 \mathrm{~m} / \mathrm{s}$ (about $\left.5(\mathrm{~L} / \mathrm{s}) / \mathrm{m}^{3}\right)$ and coming from the bin bottom, insects at $6 \mathrm{~m}$ high would be exposed to this lethal dose after 1.8 days (calculated from the equation published by Mendez et al. [37]). To control adults of $T$. castaneum, continually supplying $50 \mathrm{ppm}$ of $\mathrm{O}_{3}$ for at least 4 days was required [6] because $\mathrm{O}_{3}$ concentration inside the grain mass would decrease to less than $30 \mathrm{ppm}$ in less than $7 \mathrm{~min}$ if the $\mathrm{O}_{3}$ supply was stopped [50]. Less than $5(\mathrm{~L} / \mathrm{s}) / \mathrm{m}^{3}$ is the airflow rate for aeration. Both temperature and $\mathrm{O}_{3}$ fronts would pass the grain during the $\mathrm{O}_{3}$ treatment period. Grain would 
lose some moisture at this airflow rate in 5.8 days. This $\mathrm{O}_{3}$ fumigation time was similar to the fumigation time using phosphine. Therefore, using $\mathrm{O}_{3}$ to control insects and microorganisms and reduce mycotoxin contamination inside small farm bins was fiscally possible and could be an alternative control method. When grain was warm and wet, near-ambient drying or aeration combined with $\mathrm{O}_{3}$ treatment might have advantages over phosphine fumigation or near-ambient drying because: (1) $\mathrm{O}_{3}$ would suppress the populations of insects and microorganisms, reduce mycotoxins, and eliminate odours, improve taste, and bleach colour; (2) near-ambient drying would dry grain or aeration would cool the grain; and (3) low population of insects and microorganisms at dry and/or cold environment would not cause storage problems (depending on temperature and moisture). This treatment would at least extend the safe storage time. The $\mathrm{O}_{3}$ could be supplied from the headspace of bins and the fan could move air downward. The advantage of this method was that the fan would be exposed to low concentration of $\mathrm{O}_{3}$ and $\mathrm{O}_{3}$ might help itself move down because $\mathrm{O}_{3}$ is heavier than air. The fan could be connected with a closed-loop recirculation system to capture and reuse $\mathrm{O}_{3}$ gas. The fan could be stopped at any time because the concentration of $\mathrm{O}_{3}$ could return to previous levels in $30 \mathrm{~min}$ after $\mathrm{O}_{3}$ flow was resumed [23]. For moderately tall structures, the $\mathrm{O}_{3}$ introduction point could be any place of the grain mass and air flow could be downward or upward. There were several patents available to treat herbs, spices, fruits and vegetables by $\mathrm{O}_{3}$ treatment in small storage facilities [24, 33]. There were several pilot studies in grain storage bins [6, 19, 23, 33]. This combination method should be evaluated and compared financially with conventional methods for treatment of grain in bins.

Acknowledgments The authors thank the Natural Sciences and Engineering Research Council of Canada for partial funding of this study.

\section{References}

1. Adler MG, Hill GR (1950) The kinetic and mechanism of hydroxide iron catalyzed ozone decomposition in aqueous solution. J Am Chem Soc 72:1884-1886

2. Allen B, Wu J, Doan H (2003) Inactivation of fungi associated with barley grain by gaseous ozone. J Environ Sci Health Part B Pesticides Food Contam Agric Wastes 38:617-630

3. An HJ, King JM (2009) Using ozonation and amino acids to change pasting properties of rice starch. J Food Sci 74:278-283

4. Ballinger CA, Cueto R, Squadrito G, Coffin JF, Velsor LW, Pryor WA, Postlethwait EM (2005) Antioxidant-mediated augmentation of ozone induced membrane oxidation. Free Radic Biol Med 38:515-526

5. Beard RL (1965) Observation on house flies on high-ozone environments. Annu Entomol Soc Am 58:404-405
6. Bonjour EL, Opit GP, Hardin J, Jones CL, Payton ME, Beeby RL (2011) Efficacy of ozone fumigation against the major grain pests in stored wheat. J Econ Entomol 104:308-316

7. Bornholdt J, Dybdahl M, Vogel U, Hansen M, Loft S, Wallin H (2002) Inhalation of ozone induces DNA strand breaks and inflammation in mice. Mutat Res 520:63-72

8. Bryant EA, Fulton GP, Budd GC (1992) Disinfestation alternatives for safe drinking water. Van Nostrand Reinhold Co., New York

9. Coste C, Dubois M, Pernot A (2008) Dehulling wheat grains using ozone, US Patent Application Number: EP20070731758

10. Desvignes C, Chaurand M, Dubois M, Sadoudi A, Abecassis J, Lullien- Pellerin V (2008) Changes in common wheat grain milling behavior and tissue mechanical properties following ozone treatment. J Cereal Sci 47:245-251

11. Dollear FG, Mann GE, Codifer JLP, Gardner JHK, Koltun SP, Vix HLE (1968) Elimination of aflatoxins from peanut meal. Am Oilseed Soc 45:862-865

12. EPA (1999) Alternative disinfectants and oxidants guidance manual, Publication: EPA815 R 99014. United States Environmental Protection Agency, Washington, DC

13. Erdman HE (1980) Ozone toxicity during ontogeny of two species of flour beetles, Tribolium confusum and T. castaneum. Environ Entomol 9:16-17

14. Fetner RH (1963) Mitotic inhibition induced in grasshopper neuroblasts by exposure to ozone. USAF School of Aerospace Medicine Report No. SAM-TDR-63-39. Atlanta

15. Gomella C (1972) Ozone practice in France. J Am Water Works Assoc 64:39-46

16. Graham DM (1997) Use of ozone for food processing. Food Technol 51:72-75

17. Grimes HD, Perkins KK, Boss WE (1983) Ozone degrade into hydroxyl radical under physiological conditions. Plant Physiol 72:1016-1020

18. Hansen LS, Hansen P, Jensen KV (2012) Lethal doses of ozone for control of all stages of internal and external feeders in stored products. Pest Manag Sci 68:1311-1316

19. Hardin JA, Jones CL, Bonjour EL, Noyes RT, Beeby RL, Eltiste DA, Decker S (2010) Ozone fumigation of stored grain; closedloop recirculation and the rate of ozone consumption. J Stored Prod Res 46:149-154

20. Hoigne J, Bader H (1975) Ozonation of water: role of hydroxyl radicals as oxidizing intermediates. Science 190:782-784

21. Isikber AA, Oztekin S (2009) Comparison of susceptibility of two stored-product insects, Ephestia kuehniella Zeller and Tribolium confusum du Val to gaseous ozone. J Stored Prod Res 45:159-164

22. Jaffe LS (1967) The effects of photochemical oxidants on materials. J Air Pollut Control Assoc 17:6

23. Kells S, Mason LJ, Maier DE, Woloshuk CP (2001) Efficacy and fumigation characteristics of ozone in stored maize. J Stored Prod Res 37:371-382

24. Kim JG, Yousef AE, Dave S (1999) Application of ozone for enhancing the microbiological safety and quality of foods: a review. J Food Prot 62:1071-1087

25. Law SE, Kiss EG (1991) Instrumentation for ozone-based insect control in agriculture. In: Automated agriculture for the 21st century: proceedings of the 1991 symposium, Chicago

26. Leesch JG (2002) The mortality of stored-product insects following exposure to gaseous ozone at high concentrations. In: Credland PF, Armitage DM, Bell CH, Cogan PM, Highley E (eds) Advances in stored product protection. Proceedings of the 8th international working conference on stored-product protection. CAB International, Wallingford, pp 827-831

27. Legeron JP (1984) Ozone disinfection of drinking water. In: Rice RG, Netzer A (eds) Handbook of ozone technology and applications, vol II. Butterworth Boston, Boston, pp 99-121 
28. Lemke SL, Mayura K, Ottinger SE, McKenzie KS, Wang N, Fickey C, Kubena LF, Phillips TD (1999) Assessment of the estrogenic effects of zearalenone after treatment with ozone utilizing the mouse uterine weight bioassay. J Toxicol Environ Health Part A 56:283-295

29. Levy R, Chiu YT, Cromroy HL (1972) Effects of ozone on three species of Diptera. Environ Entomol 1:608-611

30. Levy R, Jouvenaz DP, Cromroy HL (1974) Tolerance of three species of insects to prolonged exposed to ozone. Environ Entomol 3:184-185

31. Lu B, Ren Y, Du Y, Fu Y, Gu J (2009) Effect of ozone on respiration of adult Sitophilus oryzae (L.), Tribolium castaneum (Herbst) and Rhyzopertha dominica (F.). J Insect Physiol 55: 885-889

32. Maeba H, Takamoto Y, Kamimura M, Miura T (1988) Destruction and detoxification of aflatoxin with ozone. J Food Sci 53: 667-668

33. Maier DE, Hulasare R, Campabadal CA, Woloshuk CP, Mason L (2006) Ozonation as a non-chemical stored product protection technology. In: Proceedings of the 9th international working conference on stored product protection. Brazilian Post-harvest Association, Campinas, pp 773-777

34. Mason LJ, Woloshuk CP, Maier DE (1997) Efficacy of ozone to control insects, molds and mycotoxin. In: Donahaye EJ, Navarro S, Varnava A (eds) Proceeding of the international conference on control atmosphere and fumigation of stored products. Cyprus Printer Ltd, Nicosia, pp 665-670

35. McClurkin JD, Maier DE (2010) Ozone treatment effects on microbial count on maize. In: Carvalho OM, Fields PG, Adler CS, Arthur FH, Athanassiou CG, Campbell JF, Fleurat-Lessard F, Flinn PW, Hodges RJ, Isikber AA, Navarro S, Noyes RT, Riudavets J, Sinha KK, Thorpe GR, Timlick BH, Trematerra P, White NDG (eds) Proceedings of the tenth international working conference on stored-product protection. Julius-Kuhn-Archiv, Berlin, pp 548-552

36. McKenzie KS, Sarr AB, Mayura K, Bailey RH, Miller DR, Rogers TD, Norred WP, Voss KA, Plattner RD, Kubena LF, Phillips TD (1997) Oxidative degradation and detoxification of mycotoxins using a novel source of ozone. Food Chem Toxicol 35:807-820

37. Mendez F, Maier DE, Mason LJ, Woloshuk CP (2002) Penetration of ozone into columns of stored grains and effects on chemical composition and processing performance. J Stored Prod Res 39:33-44

38. Naitoh S, Shiga I (1982) Studies on utilization of ozone in food preservation. I. Microbicidal properties of ozone on various microorganisms suspended in water. J Jpn Soc Food Sci Technol 29:1-10

39. Naitoh S, Okada Y, Sakai T (1988) Studies on utilization of ozone in food preservation: V. Changes in microflora of ozonetreated cereals, grain, peas, beans, and spices during storage. J Jpn Soc Food Sci Technol 35:69-77

40. Naitoh S, Sawada Y, Yamaguchi N (1989) Studies on utilization of ozone in food preservation: effect of ozone treatment on storage of packaged Namamen Japanese raw noodle. J Antibact Antifung Agents 17:517-526

41. Pereira ADM, Faroni LRDA, Sousa AH, Urruchi WI, Paes JL (2008) Influence of the grain temperature on the ozone toxicity to Tribolium castaneum. Revista Brasileira de Engenharia Agri'cola e Ambiental 12:493-497

42. Proctor AD, Ahmedna M, Kumar JV, Goktepe I (2004) Degradation of aflatoxins in peanut kernels/flour by gaseous ozonation and mild heat treatment. Food Addit Contam 21:786-793
43. Prozherina N, Nakvasina E, Oksanen E (2009) Impact of experimentally elevated ozone on seed germination and growth of Russian pine (pinus sylvestris) and spruce (picea spp.) provenances. J Human Environ 38:443-447

44. Qin ZG, Wu X, Deng G, Yan XP, He XC, Xi DK, Liao XW (2003) Investigation of the use of ozone fumigation to control several species of stored grain insects. In: Credland PF, Armitage DM, Bell CH, Cogan PM, Highley E (eds) Advances in stored product protection. Proceedings of the 8th international working conference on stored-product protection. CAB International, Wallingford, pp 846-851

45. Restaino LE, Frampton W, Hemphill JB, Palnikar P (1995) Efficacy of ozonated water against various food-related microorganisms. Appl Environ Microbiol 61:3471-3475

46. Rice RG, Farquhar JW, Bollyky LJ (1982) Review of the applications of ozone for increasing storage times of perishable foods. Ozone Sci Eng 4:147-163

47. Rich T (1994) A basic comparison of ozone technology. Water Technol Mag 17:51-52

48. Rich S, Tomlinson H (1968) Effects of ozone on conidiophores and conidia of Alternaria solani. Phytopathology 58:444-446

49. Rozado AF, Faroni LRA, Urruchi WMI, Guedes RNC, Paes JL (2008) Ozone application against Sitophilus zeamais and Tribolium castaneum on stored maize. Revista Brasileira de Engenharia Agri'cola e Ambiental 12:282-285

50. Santos JED, Martins MA, Faroni LR, Andrade MP, Carvalho MCS (2007) Ozonization process: saturation time, decomposition kinetics and quality of maize grains (Zea mays L.). IOA conference and exhibition, Valencia, 29-31 Oct 2007

51. Sousa AH, Faroni LRDA, Pereira M, Cardoso FS, Heberle E (2006) Influence of grain mass temperature on ozone toxicity to Sitophilus zeamais (Coleoptera: Curculionidae). In: Proceedings of the 9th international working conference on stored product protection. Campinas, Brazilian Post-harvest Association, pp 706-710

52. Sousa AH, Faroni LRDA, Guedes RNC, Totola MR, Urruchi WI (2008) Ozone as a management alternative against phosphineresistant insect pests of stored products. J Stored Prod Res 44: 379-385

53. Strait CA (1998) Efficacy of ozone to control insects and fungi in stored grain. M. S. Thesis, Purdue University, W. Lafayette

54. Sykes G (1965) Disinfestation and sterilization, 2nd edn. E. \& F. N. Spon, Ltd, London

55. Tiwari BK, Brennan CS, Curran T, Gallagher E, Cullen PJ, Donnell CPO (2010) Review: application of ozone in grain processing. J Cereal Sci 51:248-255

56. Violleau1 F, Hadjeba K, Albet J, Cazalis R, Surel O (2007) Increase of corn seeds germination by oxygen and ozone treatment. IOA conference and exhibition, Valencia, 29-31 Oct 2007

57. White SD, Murphy PT, Bern CJ, Leeuwen J (2010) Controlling deterioration of high moisture maize by ozone treatment. J Stored Prod Res 46:7-12

58. Wu J, Doan H, Cuenca MA (2006) Investigation of gaseous ozone as an anti-fungal fumigant for stored wheat. J Chem Technol Biotechnol 81:1288-1293

59. Young JC (1986) Reduction in levels of deoxynivalenol in contaminated corn by chemical and physical treatment. J Agric Food Chem 34:465-467

60. Young JC, Zhu H, Zhou T (2006) Degradation of trichothecene mycotoxins by aqueous ozone. Food Chem Toxicol 44:417-424 